\title{
3 Oita Men Troop to War
}

\section{“Leaving My Hometown"}

The attack on Pearl Harbor brought an entirely new sense of urgency, anticipation, and optimism to the vast majority of the Japanese people. But while it was a dramatic turning point in their history, it was not the beginning of war for the people of Japan, for their military had been fighting since 1931 in China. Japanese initially viewed that fight not so much as a war, but as a necessary expansion required to enhance the economic and military viability of Japan under the guise of defending Asia against Western powers. Between the Manchurian Incident in 1931 and the Marco Polo Bridge Incident in 1937, there existed a prevailing sense that the Imperial Army was easily winning, or indeed had already won, control over much of China.

It was a time when there were fewer casualties among Japanese soldiers, thus fewer families were directly impacted and people had time to mourn those killed in a traditional and respectful manner. This would change dramatically after 1941, however. For example, Kou Takeda's brother was called to military service during the war with China, but eventually died during the Pacific War in the crucial battle that took place on the small island of Saipan in 1943. He recalls in adoring detail both the day his brother left to fight and the death that followed. His recall of those transitional events is a stark reminder of the conflicted emotions felt in the homes of those who did not return home.

My family lived in a small village outside Saiki. A river ran through our village and when young men left to join the military, their families and friends saw them off at the village boat dock. From there, they'd travel down the river to Saiki. They'd board the train at Saiki station and head to their military bases.

My brother Shinjiro Takeda was conscripted in 1939. He was well liked by the villagers for being handsome and kind-hearted. I was an elementary school student at the time and looked up to him. The night before he departed, family and friends gathered for a ceremony. Many brought sake and mochi, the customary drink and snack for such occasions. During the send-off, it was common practice for the mothers and wives of soldiers to drink sake while praying to the Guardian God for the soldier's safe return. Everyone encouraged my brother to do his best for the country and for the emperor, but the truth was we really just wanted our brother to 
come back home alive. During the ceremony, he was given the traditional "thousand-stitch" spiritual belt [senninbari] to ward off enemy bullets. He wrapped it around his waist dutifully. There is nothing as pitiful as a thousand-stitch belt, because it had no effect, and we all knew it. The women made them with sadness. ${ }^{1}$ My brother woke up early the next morning before daybreak and walked to the river at the edge of the village. About a hundred people showed up to send him off with war songs. But my brother requested no war songs. Instead, my fourteen-year-old sister Misako and my brother sang a traditional song entitled "Leaving My Hometown," as he walked to the boat dock. Everyone listened quietly. Four years later my brother was killed. He had become a sergeant. During that time, my sister worked at the naval military headquarters in Saiki, and she found out our brother's unit had been deployed to Saipan from Manchuria. By this time, we'd heard that Japanese casualties on Saipan ran quite high, so we were desperately worried, fearing the worst. A month later, officials from the Saiki town office came to the house to notify the family that my brother had been killed. They brought a small box holding what they said were his remains. I couldn't believe the bones of my brother could be in that box, so I opened it in front of my family. There was only a small wooden board with my brother's name on it. No one from the military ever came to pay respects to the family. My hobby was painting and I painted a picture of my parents and my brother in his military uniform. It hung in my parent's home and I've kept this painting until now. I think of my brother every day.

Now, more and more soldiers from our village perished in battles, and their remains were sent back in white boxes. Family members would go to Saiki station to retrieve them. They'd carry the boxes and walk through the village to their homes. During the war with China, dead soldiers and their families were treated with honor. Remains of the soldiers and their personal effects were returned to their families with honor and respect. Villagers would all go and offer condolences to the families and pay tribute to the fallen soldiers. After the war started with the United States, and as the number of deaths mounted, people became hardened. They no longer treated the dead soldiers and their family with special respect. Prior to the death of my brother, I had volunteered to enter the naval training school, for I'd been a firm believer in Japan's cause. With the death of my brother, I began questioning the implications of this war.

1 This belt, a wide, light-colored cloth stitched by the women close to the soldier to ward off enemy bullets, was presented to Japanese soldiers as they left for the war. 
The fighting in China seemed distant to most except those whose sons, brothers, and husbands were sent there to fight or work. Ichiro Hashimoto grew up in Oita City during this period. "In primary school, in the mid1930s, it was rather peaceful. They were fighting the war in China but it was peaceful inside Japan. So our education didn't change. The teachers would tell us that Japan is winning the war in China and would show us articles saying we took their tanks and weapons. But the textbooks themselves did not change. I noticed the difference in education only after I entered middle school, just after the war with America started."

Yoshio Ninomiya, born in $193^{2}$ in Oita City, also recalls his teachers' lectures about this period. "I was very young, but was taught that Japan must unite Asia, besides, Japan lacked resources like oil, so had to go into Asia to get those, also fighting America and England was necessary to ensure our survival." Hideo Sonoda, growing up in Oita City, remembers, "I was born in 1931 so my youth was a time of war. In the year I was born, Japan invaded Manchuria and colonized it. When I was entering elementary school in 1937, the greater war with China started. We had military education in the schools at that time and I drew pictures of the war during those days." Pulling a large colored picture from among his papers, Sonoda said, "I drew this when I was in the third grade. It's a picture of a plane attacking in China."

Yasuo Tanaka recalls his days as an elementary school student joining his classmates as they marched to the Oita City train station to send off the soldiers on their way to China. "We were marshaled together, waiving paper flags and joining in three 'banzais' as the soldiers walked down the street and boarded the train. Then, every first day of the month we walked 20 minutes from our school to Kasuga Shrine to pray for victory."

\section{A Buddhist Priest's Gift for Hitler}

By 1939 Japan was leaning ever closer to the Axis powers of Germany and Italy. In 1936 Germany and Japan had signed the Anti-Comintern Pact, an agreement directed against communist expansion and the Soviet Union in particular. In 1938 he announced recognition of Manchukuo, the Japanese-controlled puppet state in Manchuria. The media promoted this relationship and exhorted citizens to follow the examples of these new partners, as seen in the October 1938 edition of the extreme rightwing journal Bungei Shunju, a leading militarist voice, when it declared, "You might dream of such organizations as the Nazis and Fascists. Keep in mind, however, that it is the people, united and centered on Hitler and 
Mussolini, who are moving the world."2 Solidarity with its Axis partners was encouraged throughout Japan in newspaper stories and propaganda posters, some aimed at children. This was seen clearly in a popular image of the time showing elementary age students honoring Hitler, Mussolini, and Japanese prime minister Konoe.

One Oita resident made his personal contribution in a unique and, with some historical hindsight, shocking way. The authors discovered this while touring a Buddhist temple which stands just across the field from the old naval air base and kamikaze training facility in the town of Usa. Like most Buddhist temples in Japan, the role of priest has been handed down from father to son for hundreds of years. This temple's history is traced back over 500 years, and during the war served the soldiers as both a barracks and spiritual haven. The current priest, our host and guide, represents the $20^{\text {th }}$ generation in his family line.

When one visits the temple today, the first impression is of the beauty of the architecture and the impressive, centuries-old figure of the Buddha nestled inside the golden temple shrine. However, this temple has a more complex and recent history than shown in its ancient public forum, for in a separate narrow room unseen from the worship area but located directly behind the Buddha, a stunning revelation of Japanese enthusiasm for the war effort hits in full force. It is in this private room that the priest proudly introduced to us a long row of model Japanese battleships that his grandfather constructed so painstakingly during the war years and that survived the American bombing of Usa in the latter months of the war. They were each about three feet in length. Strolling down the row of ships, one is amazed by the volume and detail of the craftsmanship. Then, under glass at the center of this spectacle, appears a prominently displayed, well preserved, personally autographed photograph and letter of thanks to the priest from Adolf Hitler. So unexpected is this historic relic that it takes one's breath away. The current priest Soei Hirata, who also serves as head of the Usa historical society, told us the story behind the autographed photo. "My grandfather's hobby was the construction of these miniature replicas of Japanese battleships. It was his passion, and you can see that they were built painstakingly of metal, molded together from scratch. As both a spiritual and community leader, he decided to do his part to honor Japan's new ally and sent Adolf Hitler one of his replicas as a gift. This autographed photo and handwritten thank-you note was the response he received from Hitler's office. Ships were also sent to Benito 
Mussolini and Japan's prime minister, Konoe, but we don't have a response from them."

Our host offered no analysis or commentary on this, only a sense of pride in the efforts made by his grandfather in constructing the ships. For him, it seems, the Hitler photo was just a small piece of the story. For us, however, it was more and as we continued down the corridor reviewing other ships the unexpected encounter with Hitler dominated our tour. This celebration of Japan's alliance with the fascists of Europe, shown starkly through this one example, reminds us just how pervasive enthusiasm for war had become by the late 1930s and how seamlessly it merged into all facets of Japanese life, including Buddhist temples, which had historically promoted a tradition of a peaceful and reflective life. ${ }^{3}$

\section{Oita Soldiers}

Oita Prefecture sent soldiers to the army in large numbers during both the China War and the Pacific War. The contributions Oita made to the war effort beginning with the China War were not just the thousands of foot soldiers sent there to fight and die for the emperor, not the military bases scattered throughout the prefecture. This otherwise undistinguished corner of the island of Kyushu also produced a surprising number of military and government leaders to guide Japan during the war. One of the most important figures was Jiro Minami. This future general was born in 1874 in the fishing village of Hiji, situated between Beppu and Kitsuki. Minami graduated from the Imperial Army Academy in 1895, with a commission in the cavalry. He fought in the Russo-Japanese War and was later assigned to commanding roles in China and Korea during the first war with China in the 1920s. In 1927 Japan's Army General Staff prepared a report arguing that Chinese resistance to Japanese expansion in Manchuria was intensifying. Rather than continue trying to win over the Chinese to a superior power with a carrot-and-stick approach, more and more Japanese began to feel that Japan should force compliance by enhancing military rule. General Minami, soon to be appointed minister of the Japanese Army, agreed. He delivered a speech in August of that year warning of the danger of Chinese nationalism moving across Manchuria, arguing that it was not a temporary condition but a permanent one. Minami and his like-minded militant officers "found

3 The authors were provided a tour of the temple by the current priest, Soei Hirata, on March 12, 2012. 
their options reduced to the extremes of ignominious retreat or a violent push forward." ${ }^{4}$

After the war in China began anew in 1931, General Minami returned to China as head of the Kwantung Army and, at the same time, Japanese ambassador to the court of the puppet Manchurian emperor Puyi, who had been installed by the Japanese in an attempt to legitimize their incursion into China. At the same time, he served as governor general of Korea and, toward the end of the war, was appointed a member of the Diet and Privy Council to the emperor. ${ }^{5}$

During the war with China and then the Allies, Oita's contributions multiplied, as Minami was joined by other Oita natives who became, respectively, supreme leaders of the Imperial Army, Navy, and diplomatic corps. Each played a key role in deciding vital military and diplomatic strategies from the 1930s through the end of the war. It is also instructive to note that all three were uncompromising militarists who played pivotal roles in the enthusiastic beginnings of the war and its futile continuation even to the very end. Their roles will be explored more fully in later chapters, in discussing the final days of Imperial Japan.

Representing Oita on battlefields around China and the Pacific were men from the $47^{\text {th }}$ Oita Regiment, with soldiers recruited from throughout the prefecture. This unit first fought in China in 1933 to support Japan's goal of controlling northeast China in its entirety after the Manchurian Incident. Arriving on December 21, 1932, the $47^{\text {th }}$ engaged Chinese troops almost immediately after the New Year, moving toward Beijing. By April 10, according to an account by an Oita reporter well after the war, "the colors of the $47^{\text {th }}$ regiment were brilliant atop the Great Wall." By October of 1933 the Japanese Army, having gained control of more territory, signed a cease-fire and the $47^{\text {th }}$ "returned to Oita with glory." They would not return to China until 1937, when they took part in some of the bloodiest fighting in the war.

In the summer of 1937 men of the Oita $47^{\text {th }}$ received orders to mobilize for a new assignment in China with Colonel Masanori Hasegawa in command. At 5:15 p.m. on August 1, all members of the regiment gathered at the local Meiji Shrine, located in front of their barracks. They prayed for victory in

4 Yoshihisa Tak Matsusaka, The Making ofJapanese Manchuria, 1904-1932 (Cambridge, MA: Harvard University Press, 2001), p. 355.

5 C. Peter Chen, "Jiro Minami," World War II Database, http://ww2db.com/person_bio. php?person_id=362; “Minami, Jirō,” Generals.dk, http://www.generals.dk/general/Minami/ Jir\%C5\%8D/Japan.html. After the war Minami was classified as a Class A war criminal, found guilty of the charges against him concerning aggression in China, and sentenced to life in prison. He was paroled in 1954 and died in 1955 . 
their upcoming fighting in China. They then walked through Oita City to the train station, where citizens had gathered to cheer them on. On August 3, they boarded a ship in Moji Port, stopping in Busan, Korea, on their way to setting up Camp Zhujaiwu, just south of Beijing. There they joined other troops in the $1^{\text {st }}$ and $2^{\text {nd }}$ armies in maintaining order and security in the area, awaiting battle orders.

Those orders came on August 31. The $47^{\text {th }}$, known also as the Hasegawa Regiment, received orders to move southwest and attack the city of Baoding. Before departing, Colonel Hasegawa was given fighting orders, along with the following instruction by his commander, Takagai. "Always cremate the war dead in a careful manner and send back the remains to the families of those soldiers. Also, your men are prohibited from raping and foraging." At this stage of the war, it was still feasible to send remains back to the families. As for the prohibition on raping and foraging, the growing intensity and horror of the war overtook such humane orders.

Over the next several weeks the $47^{\text {th }}$ fought their way through stiff Chinese resistance to the edge of Baoding. Following is the regimental history of the role the $47^{\text {th }}$ played in taking the city.

All were exhausted. In the silence of the night, Captain Torao Eshima was given the grave responsibility of creating a pathway to attack the enemy. He was ordered to send three soldiers on a suicide mission to breach the wall, opening up an entry point for the other soldiers. Eshima ordered $9^{\text {th }}$ captain Seitaro Abe to choose three men for this mission. They were Sergeant Takara Ishida, Lance Corporal Akiyoshi Goto, and Junior Technician Ashikari Kosaku. Each one only took a dagger and a hoe. They ran out from the trench and moved to the bottom of the castle wall. The enemy was alert and began tossing hand grenades at them. Fortunately, none of the grenades hit them. They decided to climb up the side of the wall step by step. Ishida went first, then Goto and Ashikare. Ishida lost his footing, and Goto took his place at the top. Ten minutes later all three reached the top. However, a small group of Chinese troops spotted them. Goto grabbed a gun with bayonet from the enemy and began shooting. Ishida and Ashikare followed, also capturing weapons. The three were now at the top of the castle, looking down the stairway entrance where about 100 Chinese soldiers attempted to come up to attack the suicide team. But they were blown away by the three men of the $47^{\text {th }}$ and ordered to surrender. The enemy didn't understand Japanese but they put down their weapons and surrendered. Goto took out a flag from his uniform and placed the Rising Sun over the north gate. The team opened the heavy 
door of the north gate and their comrades rushed in. It was 9:10 a.m. on September $24,1937 .^{6}$

This record is reminiscent of heroic war stories found throughout history, and some of the details have surely been embellished over the years. However, it is not disputable that the city of Baoding was taken, and that the members of the $47^{\text {th }}$ were at the forefront of the battle. For the $47^{\text {th }}$ and most other Japanese troops in China at this time, the brutality of the war was just beginning. After Baoding the Oita men pressed southward to join the battle for southern China, arriving just after the Japanese victory in Shanghai in late November.

As the $47^{\text {th }}$ pushed inland Shunsaku Nanri, the young Japanese boy living in Shanghai with his parents, remembers watching the buildup of Japanese troops in the area.

I was born in Dalian, where my father ran a trading company. We moved to Shanghai, where I began the first grade in a Japanese school. There were a few Chinese and some Korean students in my school, but they were all Japanese nationals. We lived in the Japanese concession of the city, where there were elementary, middle, and high schools, as well as universities. My life was comfortable and safe. In the area where I lived were stationed about 2,000 Japanese sailors, so the Japanese in Shanghai were not worried for our safety. However, in the summer of 1937, during a school break, fighting broke out in the streets of Shanghai between the Chinese and Japanese armies. My family was advised to evacuate to a safer place. Our neighbor had a car and took us to the Japanese Club with others. We stayed there for about two weeks, away from the fighting. Then more and more Japanese troops came to the city, and the children were taken out of Shanghai. We boarded the ship Tsuwa Maru to Nagasaki. A few days later, we arrived at my mother's hometown of Beppu in Oita.

\section{On to Nanjing}

After the victory in Shanghai, the Oita $47^{\text {th }}$ Regiment was incorporated into the newly formed $10^{\text {th }}$ Army, led by General Heisuke Yanagawa, and then were attached to the $6^{\text {th }}$ Division, which was destined to lead the charge in

6 Takashi Hiramatsu, Battle History of Our Hometown Troops (鄉土部隊奮戰史) (Oita: Oita Godo Press, 1983), pp. 115 and 140. 
the coming Battle of Nanjing, the capital of Chiang Kai-shek's government. While Imperial Headquarters in Tokyo contemplated how best to follow up on the surprisingly difficult victory in Shanghai, on November 19 the $10^{\text {th }}$ Army's General Yanagawa, with fresh troops ready for action and without authorization from his commanders, brazenly ordered the men of the Oita $47^{\text {th }}$ and other regiments to follow and eradicate the Chinese Army fleeing Shanghai toward Nanjing. He wrote to his superiors, "The overall situation right now will not allow us to call off the Nanjing campaign. Also, I have a belief based upon my sixth sense that we can capture Nanjing easily by pursuing the enemy." This action caused consternation in Tokyo, as no attack on Nanjing had yet been announced. But it was too late to override the order and, like other important decisions in the war, high-spirited leadership on the ground overwhelmed central authority, and the troops forged ahead. On November 24, the General Staff issued the following instructions: "It is now no use to operate within the previously determined operation area in view of the situation of our troops and theirs [the Chinese]. In addition, a part of the CCAA [Central China Area Army] has already moved beyond the said area and is pursuing the enemy by capitalizing on its confusion. Accordingly, the operation restriction line ... will be abolished owing to circumstances beyond our control."

On November 30, the $47^{\text {th }}$ Regiment received orders to move quickly to Nanjing before the panic exhibited in Chiang Kai-shek's army after the fall of Shanghai could be repaired and the army reformed. Japanese bombing of Nanjing commenced, wreaking havoc throughout the city. Expecting little resistance and a quick victory, the officers ordered their men to take with them only essential fighting gear and medical supplies. Rations were not distributed prior to the attack, leaving soldiers to forage through the towns and villages encountered along the way. Uncontrolled looting, pillaging, and burning of villages followed in their wake. However, despite the chaos in the Chinese ranks, advancing was not as easy as anticipated, and several battles took place in which individual Chinese units regrouped and beat back the invaders, killing many Japanese soldiers.

On December 10, the $47^{\text {th }}$ participated in an all-out attack along the retreating Chinese Army's front by taking the heights protecting the southern gate of the city. Fighting was again surprisingly fierce, with many killed and wounded. But the Japanese eventually reached the heights overlooking Nanjing. Now they prepared to cross the city moat and take the city. On

7 Quoted in Masahiro Yamamoto, Nanking: Anatomy of an Atrocity (Westport, CT: Praeger, 200o), pp. 49-50. 
the following day, the $6^{\text {th }}$ Division concentrated artillery fire on the city's southwest gate while members of the $47^{\text {th }}$ were ordered to lead the charge into the city. The $3^{\text {rd }}$ Company of the $47^{\text {th }}$ began the attack on the night of December 11, crossing the moat on sampans and burning houses at the base of the wall to create a smokescreen. Six members of $3^{\text {rd }}$ Company then formed a suicide squad, climbing 20 meters up makeshift bamboo ladders to the top of the wall. One soldier fell into the moat while climbing, and four more were killed as they breached the top of the wall, but one young man named Nakatsuru climbed over the wall and into Nanjing. He was followed by members of other units. The Japanese $10^{\text {th }}$ Army, led by six men from Oita, had established a foothold in Nanjing that expanded quickly to Japanese occupation of the city. On December 17 , the $47^{\text {th }}$ participated in the formal entry ceremony of the army into Nanjing. ${ }^{8}$

\section{Nanjing Legacy and the Pride of Oita}

The success of the $47^{\text {th }}$ in these early battles in China instilled pride and confidence in the community and drew young men from Oita to join the unit when they reached the age of conscription. One such man was Shukichi Make, a young farmer who joined the $47^{\text {th }}$ in 1940 and rose to a command position before the end of the war. After the war he served as standard bearer of the $47^{\text {th }}$ s legacy, serving as the leading figure in organizing annual reunions and social services on behalf of former soldiers as they grew older. His memory of life with the Oita $47^{\text {th }}$ is replete with bravado and conviction in both the correctness of the war and the actions of the men under his command. In his mind, some 70 years after the battles had gone silent, it was the enemy who was cruel and deceitful, not his army.

When I was asked which regiment I wanted to join, I answered "the $47^{\text {th }}$." At the time I joined up, the $47^{\text {th }}$ was at the front line of war in China after occupying Nanjing. I wanted to join this unit for two reasons. First, this was the regiment of my hometown. Second, it was the strongest regiment in Japan. I wanted to be part of such a regiment. I was assigned to officer training. As an infantry soldier, I learned proper use of machine guns and

8 Yang Tianshi, "From Fightin at the Marco Polo Bridge, July 1937, to the Fall of Wuhan, October 1938," in The Battle for China: Essays on the Military History of the Sino-Japanese War of 1937-1945, ed. Mark Peattie, Edward J. Drea, and Hans van de Ven (Redwood City, CA: Stanford University Press, 2011), p. 178; and Hiramatsu, “Timeline of the Oita $47^{\text {th }}$ Regiment," pp. 203-204. 
cannons. Geometry was also compulsory for those of us learning how to use artillery. I also learned how to organize my men during a battle, how to order attacks, and how to focus on targets. In addition to these technical activities, I learned the Bushido Spirit - willingness to die to obtain glory and human fulfillment - from those that fought in the early $1930{ }^{9} .^{9} \mathrm{I}$ learned that leaders must work for the good of the country and be ready to die. I would run to the shrine located at the corner of the military academy every day after roll call to pray. I was trained in sword fighting, mountain climbing, kendo, and judo, as well as spiritual education. A story of three brave soldiers from our unit that we would follow into China was held up as a glorious example to the new soldiers. The three brave soldiers wrapped small bombs on their bodies, and together they charged at the enemy. These men were our role models, and we took pride in following their footsteps. One can say that members of the $47^{\text {th }}$ had the spirit of the kamikaze even before the Pacific War started. Yes, Bushido Spirit in Japan was there! ${ }^{10}$

Captain Make's family supported, indeed encouraged, his enthusiasm for the fight.

The night before I left for China, my family held a dinner for me. They encouraged me to fight bravely for Japan. My father, who had fought in a previous war in Siberia for Japan, told me that I should always remain calm and be ready to die, because I was Japanese. He also gave me his sword to remember him by. The women in my family had prepared a thousand-stitch belt for me to wear for protection against enemy fire. I kept it until the end of the war. Unfortunately, I was forced to hand it over to the enemy at the time of surrender. My mother tried to hide her teardrops. This was a typical family scene at the time.

Captain Make did not participate in the 1937 Nanjing attack, as he joined the military in 1940. However, he did serve with many of those who fought in Nanjing. He still insists that the actions of his fellow soldiers in the battle for Nanjing were appropriate in the rules of war, and the success in Nanjing played a part in his eagerness to join the $47^{\text {th }}$. With swelling pride, he argues,

9 Bushido involves not only fighting spirit and fighting skill, but also absolute loyalty to one's highest authority, personal honor, devotion to duty, and the willingness to die in battle or through an honorable suicide. Roger Davis and Osamu Ikeno, eds., The Japanese Mind (Tokyo: Tuttle Publishing, 2002), pp. 41-42.

10 In 2013 Captain Make, at 94 years old, still served as the leader of those few remaining members of the $47^{\text {th }}$ memorial organization. 
“The $47^{\text {th }}$ was one of the army's strongest regiments, fighting at the very front of the battle in Nanjing and many other battles thereafter. The reputation of our regiment was to fight, occupy, and then move ahead to the next battle. The $47^{\text {th }}$ was the first to arrive at the city gate of Nanjing and put up our flag." On the question of a massacre, Captain Make insists, "I don't believe there was a massacre." Any fault for excesses, he insists, falls to the Chinese military leaders who abandoned their troops, leaving the area in chaos and without leadership. Showing disdain for Chinese military leadership some 70 years after the war, he continued:

The Chinese military was undisciplined, unscrupulous, and cruel. On July 29, at the Battle of Tongzhou on the way to Nanjing, more than 200 of our soldiers were killed in the cruelest way. And at the Battle of Nanjing, the Chinese leaders totally abandoned their troops. In the chaos, the Chinese soldiers took off their military uniforms and mixed in with local citizens. This lack of order and discipline on the part of the Chinese and their cruelty were the cause of the confusion in Nanjing. You'd never see a Japanese officer run away from his responsibilities.

Emphasizing the orderliness exhibited by the $47^{\text {th }}$, Captain Make recalls proudly how he led his men.

We had strict orders to be disciplined. Depending on the cooperation from the residents in the city, rules were adjusted. For example, we were not allowed to drink the local water and had to check the feeding supplies for our horses to make sure they were not poisoned. Also, the men were not allowed to go out at night, because it might cause unintended problems with the local residents. In fact, we were always in a hurry to get to the next city and took no time to communicate with the local people. I personally never had to beat my men since they were well disciplined, though I know that happened in other regiments. For those in our unit who did break rules, we put them under detention. Also, after each battle, a small number of soldiers from the regiment were assigned to maintain peace and order in the towns we entered. These men would communicate with the leaders of the town or village, such as mayors or village heads. We did have sympathy for the enemy and wanted the local people to have peace again. Whenever we left a town, we'd distribute medical supplies and food to them.

This sanitized representation of Japanese intentions and actions from Captain Make fit well with the sentiment the Japanese government wanted to 
convey to the people of Japan during the war. This was especially prevalent in the training and indoctrination received by the soldiers prior to shipping off. Historians Haruko Taya Cook and Theodore F. Cook spell this out in the introduction to their book, Japan at War: An Oral History.

The Japanese people, and the army in particular, were ... steeped in a deep sense of superiority to other Asians. Japan was paternalistic in the best of times. It often presented itself as an older brother "leading the newly emerging members of the Asian family toward development." Such feelings, and a code of behavior that placed little value on the rights and privileges of an enemy population, left Japanese soldiers and civilians capable in wartime of committing shocking and widespread war crimes ... without a prevailing feeling that these were morally reprehensible. ${ }^{11}$

In fact, not only did the Japanese look down on the inferior Chinese, they were clearly racist. As one former solder remembers his own cruelty, "we were implanted ... with racism.... We disparaged all other races. If we didn't have a feeling of racial superiority, we couldn't have done it."12

Therefore, when the Chinese actually fought back with intensity and, at times, cruelty akin to that they had experienced from the invaders, Japanese soldiers were shocked and lashed out at what they considered ungrateful inferior people they had come to help. More than seven decades later, Captain Make still defends the actions of his fellow soldiers, who in his mind could not be faulted for their brutality. It is illogical, of course, but this is what Captain Make and his fellow soldiers were taught. They accepted these views unequivocally and the views forever imprinted in their psyche. For a "good soldier" like Captain Make to think otherwise would be to dismiss what he had, in turn, taught his men and to discredit his fallen comrades.

The events surrounding this attack and the occupation of Nanjing have been debated for decades, with many in Japan refusing to acknowledge the atrocities documented by eyewitness accounts from Chinese, foreign residents of Nanjing, and some former Japanese soldiers. Yet following the war some Japanese did acknowledge the excesses in Nanjing. Even in the home town of the Oita $47^{\text {th }}$, the Nanjing massacre is acknowledged:

11 Haruko Taya Cook and Theodore F. Cook, Japan at War: An Oral History (New York: The New Press, 1992), p. 25.

12 Tamura Yoshio, "Unit 731," quoted in ibid., p. 164. 
On August 1, the $47^{\text {th }}$ Oita Unit moved into China. They soon marched from Shanghai to the battle at Nanjing, helping raise the flag of the rising sun over that city. However, at this time, the Japanese troops lashed out against the Chinese in what is infamously known as the Rape of Nanjing. Not only were Chinese soldiers and civilians murdered, but there were many cases of looting, arson, violence, and rape. This incident is the perfect example of how war makes people mad, crazy. The number of afflicted persons is still debated, although the Chinese government believes it to be at least 300,000. At the time, information about the war was heavily censored and such acts as carried out by the Japanese soldiers in China were not reported at all. The Japanese public, unaware of how horrendously their troops were behaving, celebrated the multiple victories in Shanghai and Nanjing, shouting "Kougun banzai," or "Heaven praise the Imperial Army." The local newspapers called for the populace to participate in "flag parades by all citizens" and in Oita City 23,000 people gathered at Shirosaki Shrine to give praise for the continuous victories by lighting lanterns and carrying flags. $^{13}$

Most of the stories appearing in the Japanese press during and immediately following the attack on Nanjing were reported by a group of reporters and propagandists organized as the "Pen Corps." Reporting to the Japanese Army's military intelligence unit, they accompanied the soldiers into Nanjing and many other cities in China, describing the glorious victories of the Japanese Imperial Army. Oita newspapers, like those throughout the country, depended on these stories to educate the citizenry. ${ }^{14}$ The excitement over the victory in Nanjing was exhibited on the cinema screen as well as in print. In a 1938 film titled Nanking, soldiers returning to the front line after being wounded during the Battle of Nanjing were extolled as treasures of Japan. In cinemas across the country, the Japanese populace watched soldiers departing the military hospital, responding to "orders to return to duty where they will dance a jig of joy and others will envy them terribly." Then, as the soldiers march out of the hospital compound in Nanjing, they are joined by nurses and doctors in singing a military tune affirming their duty to fight and die rather than surrender: 
We punish evil

Our soldiers of loyal valor and giant strength

Travel far from their parents' country now with joyous shouts

With soulful bravery

We swear we will never come back alive if we lose $\mathrm{e}^{15}$

\section{Our Chinese Family Meets the $47^{\text {th }}$}

Among the Chinese, fear of Japanese atrocities spread with the movements of the Japanese Army. The following firsthand account of a refugee family shows this fear and desperation vividly. It is a personal story for the authors, arising from our research on the history of the $47^{\text {th }}$ Oita Regiment's activities in China. The authors were dismayed to find that in the days and weeks following the Japanese attacks in Nanjing and surrounding areas, the $47^{\text {th }}$ occupied the strategically important town of Wuhu. Wuhu is the home town of Ran Ying's mother and Ran Ying lived there as a young girl for several years during the 1950s. Her aunt, Ma Jifeng, shared memories with Ran Ying of her family's experience during the war. Over the years her memories were recorded by family members and they now provide a record of that time. The Battle of Nanjing and the ensuing occupation of Wuhu, then, had become much more intriguing to us, as we could follow the path of the $47^{\text {th }}$ and see the intersection with Ran Ying's family at this historically important juncture in the war. The following stories come from the memories of Ma Jifeng and her cousin Ma Jisen, Ran Ying's mother.

As the Japanese Army moved inland from Shanghai in the fall of 1937, families gathered what personal belongings they could carry and moved south by whatever means possible. One such group of refugees was the Ma family of Wuhu, a town soon to be occupied and administered by the Oita $47^{\text {th }}$ Regiment. The family patriarch, Ran Ying's great-grandfather, sent his two sons, two daughters, and their families, along with other relatives, to join the river of refugees escaping Japanese rule. The oldest was 45 , the youngest less than one year old. One daughter and one daughter-in-law were pregnant. They had no final destination in mind, only to escape the Japanese. Twenty-one members of the family evacuated to the south, with

15 From the 1938 Japanese documentary Nanking, http://wapwon.cc/video/Precious-film-ofsoon-after-the-Fall-of-Nanking36s/bpIQ7wQbKaE. It can also be found on YouTube: https:// www.youtube.com/watch?v=bpIQ7wQbKaE. No credits are available for this film, but it is clearly a wartime propaganda film distributed by the Japanese government. 
only the patriarch staying behind to watch the family home and restaurant business. The granddaughter of the patriarch, Ma Jifeng, who was fifteen years old at the time, remembers that as they evacuated Wuhu, and for much of the rest of the journey, the sky was red with fire, and filled with airplanes dropping bombs.

As we moved south, we found ourselves running away with the Kuomintang soldiers retreating from the Japanese who, we were told, were just behind us. We moved along with masses of panic-stricken refugees toward Changsha, which was about goo kilometers from Wuhu. When we reached Changsha everyone was exhausted, but even there we were told the Japanese were coming, so we forged ahead, going further south. We did not stop for eight days and nights until we arrived in Guangzhou, another 700 kilometers away. In the chaotic streets of the city, like everyone else, we searched for any safe haven we could find. We asked one of the Catholic Church priests for sanctuary, but were refused and ended up sleeping on the street. Guangzhou was not safe. My uncle was robbed of all his money by Kuomintang Army deserters, the family was cheated by local criminals, and businessmen took advantage of our plight. With all hopes dashed, my father led us back toward Changsha. During the return trip to Changsha my grandfather, two of my uncles, and one aunt died, and both my mother and my aunt had miscarriages. But we could not stop to let them rest, and they were forced to keep up with the family. In Changsha, we found that panic had grown deeper as the Japanese drew closer. With no place to turn to, my father decided that we should return home to Wuhu. Failing in our escape, exhausted, and missing home despite the fear of Japanese soldiers, we began the goo kilometer journey home. Exhaustion, starvation and sickness continued to take its toll along the way, as another uncle died, as did my one-year-old cousin. On January 5,1938 , those of us who were still alive, now only fourteen in numbers, returned home to Wuhu. ${ }^{16}$

During the months of this family's ordeal, the Oita $47^{\text {th }}$ moved on from Nanjing and established its regimental headquarters in the nearby town of Ningguo. In January, the Oita soldiers fought several battles and served as escorts for high-ranking officers inspecting the front, including newly appointed division commander Shiro Inaba. "When he came to inspect the $47^{\text {th }}$, his first battlefront visit, the regiment dispatched an escort force for him 
and they fought back against enemy snipers trying to hit the commander's vehicle. ${ }^{{ }^{17}}$ After the Nanjing operation, Japanese troops adopted a defensive posture, which demoralized the men. To counter this and keep morale high to maintain battle readiness, the officers sent them on limited engagements to 'intensify territorial control through 'punitive expeditions' and calling for frequent 'red alert drills."' ${ }^{18}$ The defensive posture was adopted as a response to the unexpectedly fierce resistance by Chinese troops between Shanghai and Nanjing. The historian of the Oita $47^{\text {th }}$ recounts:

During this time, hopes that the war would end soon were dashed, and this phase of the war was a deadlock. It looked to be a war of attrition. At the end of 1937, the Japanese deployment throughout China numbered sixteen divisions, with about 500,000 soldiers. As the battle lines were extended, exhaustion could be seen in the Japanese troops. Widely scattered Japanese fortifications were easily attacked by guerrilla forces, which forced our troops to engage in endless expeditions against them, exposing our men to much danger. As spring approached in March, Chinese guerrilla activity increased, and the $47^{\text {th }}$ Regiment deployed forces to various districts every day to undertake further punitive actions against the enemy. Without coordinated resistance by the guerrilla forces, our casualties were minimal. But when we pushed them, they pulled out and when we pulled out, they pushed us. It was quite impossible to fully expel them. On March 24, the regiment was redeployed to Wuhu where the $6^{\text {th }}$ Division was stationed. In Wuhu, a key river junction, we continued to fight local guerrillas, patrol the city, and carry out training drills every day. ${ }^{19}$

The populace was closely watched, since no Chinese were trusted, and guerrilla action continued apace. In Wuhu, however, the $47^{\text {th }}$ not only had to worry about the Chinese, but also some Americans. There in the north side of the city stood a hospital run by American Methodist missionaries atop a small hill. "As it was surrounded by difficult terrain, it was extremely well positioned to hide spies and anti-Japanese resistance fighters. Our soldiers approached the American director of the hospital, voicing their concerns. As a result, a patrol center was set up inside the hospital and an armed sentry posted outside the front door." ${ }^{{ }^{2} 0}$ 
For the most part, however, the Japanese did not interfere in the daily lives of most people in Wuhu, as policing and training in the area took most of their time. Ran Ying's mother, Ma Jisen, who survived the evacuation and return to Wuhu, remembers seeing Japanese soldiers patrolling the streets of Wuhu from the time of the family's return throughout most of the remaining years of the war. For the most part, it seemed, there was no interaction between the soldiers and the citizens. However, she remembers:

We often saw Japanese patrols in the streets, walking in single file and singing some Japanese song or other. The local residents had nothing to do with them on a daily basis. After I started school, there was a Japanese girl in my class, and she was fond of playing with me. Now that I think of it, her father must have been a businessman for her family lived in a flat near my home. I was young, so did not think too much and played with her as I did with my other friends. But, I know my family was worried about the older girls, so they were kept as far away as possible from the Japanese soldiers. During that period, my older cousin, Ma Jifeng, entered a Catholic School where she boarded. She would not come home for months at a stretch even though the school was right behind our home. When she finally came home, it was to be married off, almost immediately. This was because stories circulated that Japanese soldiers' going to local residents' homes searching for virgin girls. These intrusions happened in my friends' homes and they suffered at the hands of some Japanese soldiers.

\section{Securing Victory and Moving On}

As the Ma family returned to an occupied Wuhu, young Shunsaku Nanri, the boy who evacuated from China to Beppu in 1937, boarded a ship to return to his family in Shanghai, now under Japanese control.

In 1938, after the Japanese had taken control of Shanghai, I returned to be with my family there, leaving only at the end of the war in 1945. By then the atmosphere in Shanghai had changed, and we were warned in school to be cautious at all times. When I entered middle school, I participated in military training drills, marching and fighting. From the second year we were taught to use guns, although there was no bullet in the guns. The guns we carried in training were old-fashioned models. They were long and had been used during the Russo-Japanese War. Just before the end of the war, when I was in the third year, we would have 
live-fire exercises. My life was pretty much like students my age inside Japan. The content of our education was entirely Japanese. Apart from having Chinese servants and seeing Chinese walking on our streets, we lived in a completely Japanese community. In many ways, it was life as usual for the children. We even took vacation trips to other cities like Beijing and Lushan.

The $47^{\text {th }}$ Oita Regiment had not left Nanjing unbruised. Back in Oita, on February 13, 1938, a memorial service was held at the Oita military training facility for the 193 soldiers who had died in that campaign. There would be many more such services, as the Japanese forces - including the $47^{\text {th }}$ Oita unit in the middle of the fighting - began to sustain more and more casualties as they pushed the Chinese Army out of other cities, including Wuhan and Guangzhou. ${ }^{21}$ The stream of death notices, cremated ashes, and personal effects from dead sons and husbands, brothers and uncles grew over the years. Eventually orderly notification by an overwhelmed military ceased, leaving families with no option but to wait and see if their loved ones would ever come home.

By the late summer of 1938 the Oita $47^{\text {th }}$ departed Wuhu, moving to new battles in Guangji, Fenghuang Shan, and Hankou (current-day Wuhan). On September 15 Colonel Hasegawa handed over command to Colonel Tamio Iwasaki, recently arrived from Korea. The battle for Hankou was just entering a fierce stage, and the new commander inherited a weakened force. Demoralized from defensive strategies and suffering from malaria and poorly treated wounds and illnesses, he had much work to do. Finally, he succeeded in rallying his soldiers and on October 25 , the $47^{\text {th }}$ entered Hankou as part of the victorious $10^{\text {th }}$ Army. On November 3 , the emperor's birthday, a victory celebration was held in the city. From that time until the late summer of 1941 , the $47^{\text {th }}$ regained its strength and fought battle after battle in China, finally occupying the port city of Fuzhou between April 21 and September 3, 1941. From there it eventually moved to Taiwan, the Philippines, and Indonesia. ${ }^{22}$

21 Hoashi, p. 9.

22 Hiramatsu, “Timeline," pp. 244, 281, 292, 333,533; Tobe Ryoichi, "The Japanese Eleventh Army in Central China, 1938-1941," in The Battle for China: Essays on the Military History of the Sino-Japanese War of 1937-1945, ed. Mark Peattie, Edward J. Drea, and Hans van de Ven (Redwood City, CA: Stanford University Press, 2011), p. 214; “The Bataan Death March,” Asian-Americans \& Pacific Islanders in the United States Army, http://www.army.mil/asianpacificamericans/ history. 
While the Oita men marched across China, the pilots stationed at the naval air base in Saiki supported them by attacking Chinese cities from the air. Kou Takeda recalls:

I remember that the aircraft the navy used in the 1930s were the old biplanes. But we could see that the technology changed very quickly over ten years and biplanes were replaced by new types of single-wing aircraft. When the war started with China, the planes sent to attack China flew mostly from Saiki. Particularly the heavy bombing of Chongqing in 1938 was led by the Saiki Naval Air Force. When the planes left from Saiki, they joined with other aircraft at Omura Air Base in Nagasaki and flew on to China. They returned back to Saiki via Nagasaki. These flights were secret, and the local community never knew when they would leave or return. But we were very happy because we knew that Japan was winning the war with China.

Stopping for a moment to collect his thoughts, Mr. Takeda, who was over 80 years old in 2012 when he spoke at the local Peace Museum to commemorate the history of Saiki in World War II, shared an insight he had recently gained. "Only in the past few years, after talking with Chinese visitors to the Saiki Peace Museum, did I discover how much the Chinese people suffered because of the war with Japan, especially from the bombing by Saiki pilots. We, the perpetrators, never thought of this from their perspective." The horrors of these air attacks, aimed primarily against a civilian population, were kept secret from young Kou and all Japanese citizens for the duration of the war, and were rarely mentioned in the postwar era. In fact, the planes from Saiki took part in the massive bombing of Chongqing that started in May 1938 and continued even after the Pearl Harbor attack. In the initial attack, incendiary as well as conventional bombs were dropped, and in just two days more than 5 ,000 Chinese citizens died from the bombing. ${ }^{23}$

As the war in China intensified and Chinese resistance to the Japanese slowly gained in organization and strength due to the united front formed by the forces of Chiang Kai-Shek and Mao Zedong, battles raged across the country. The $47^{\text {th }}$ Oita Regiment, as we have seen, was in the thick of these battles. But not all soldiers from the regiment joined in the fighting; some stayed behind to train the new recruits. One trainer for the $47^{\text {th }}$ was Naomasa Kodama from Usuki, an ancient and historic Buddhist village with large statues carved into the hillside above the river south of Oita City. 
Like Captain Make, he joined the $47^{\text {th }}$ in 1940, having just turned 21, and eventually reached the rank of sergeant. Kodama's entry into the army was typical of many. Upon turning 20 and receiving his invitation to take the examinations to join the army, he reported for duty and passed all exams, both physical and written. The night before reporting for duty, Kodama's family and friends celebrated his acceptance into the $47^{\text {th }}$ at the local community center with eating and drinking, singing and toasting. He recalls:

On that evening many people wrote messages to me on a small Japanese flag. When my three brothers left for the army they received the same gift. I lost mine at the end of the war, but still have my brothers' flag. The women in the community also gave me a thousand-stitch belt to bring me good luck and protect me. I eventually took it to war with me, but I don't have it any more. The enemy burned it when the war ended for me in Indonesia.

Before going overseas to fight, Sergeant Kodama spent six months training in Oita, and then became a trainer himself.

Most in our unit were sent to war, yet somehow I was one of the few who stayed behind. At that time, the military classified soldiers into two types. One was active-duty professional soldiers (genekihei); the other was replacements, or backup soldiers (hojyuhei), who were needed to fill the ranks depleted by growing numbers of casualties. Oita had been designated as one of the training camps for the replacement soldiers who would serve up to two years and then return home. I remained in Oita for two years and was put in charge of training the newly conscripted soldiers. I took them to the training ground near Beppu, where we practiced throwing hand grenades from the top of Jumonjibaru Mountain. I taught them to shoot weapons and to sword fight in close combat. The training was very strict in Oita, in order to get them ready for what they would encounter in real combat. Everyone had to abide by military rules. If one person made a mistake, the whole group was punished. For example, if one soldier didn't bow properly, all in that unit were beaten, and then they had to stand at attention for a very long time while holding their rifles. I'm telling you, those rifles were heavy.

Finally, in 1942, Sergeant Kodama was relieved of his training responsibilities and sent overseas to join Captain Make and the rest of the $47^{\text {th }}$ just after it had left China. First he joined them in Taiwan, and then they went off to 
the Philippines for a short tour of duty. The $47^{\text {th }}$ then shipped off to Java for six months, finally stopping for the next three years in East Timor, where they stayed until the war ended.

I remember being surprised that the Philippines was more developed than I'd expected. They even had a tape recorder of some sort playing music in the cabaret those days. The people of Surabaya on Java were very nice to us, and when we moved to Timor we saw people walking around without shoes. I liked the native people there and spent time with them. There was little fighting on Timor, as the Portuguese soldiers had left. On Java I had my first experience of combat. We fought the Dutch, who were big and strong, but we Japanese won. I saw Dutch soldiers die, and Japanese soldiers die. One morning, I woke up to find 50 soldiers from my unit dead, just lying on the ground. Sometimes, local guerillas attacked us, mostly small incursions, nothing too fierce. In those battles I never felt any hatred toward the enemy; I didn't feel anything special really. It was just war. 